\title{
Bedre pasientsikkerhet?
}

En meldeordning som trådte i kraft i 2012, skulle bidra til å øke pasientsikkerheten og redusere uønskede sykehushendelser. På oppdrag fra Helse- og omsorgsdepartementet har Sintef evaluert ordningen. Resultatet er en rapport som konkluderer med at kriteriene for hva som skal rapporteres er uklare.

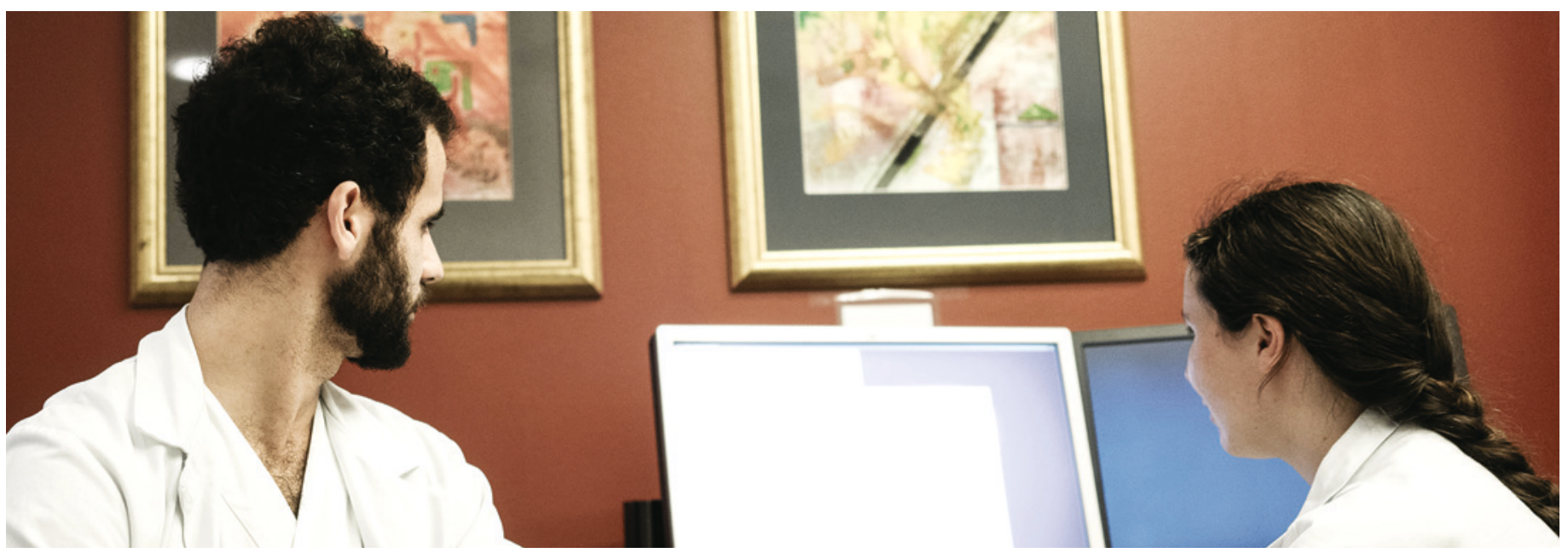

Illustrasjonsfoto: Ole Kristian Losvik

Hensikten med evalueringen var å finne ut om pasientsikkerheten ble bedret og om meldingene kunne brukes til å finne årsak til feil og dermed unngå gjentakelse av disse.

\section{Lære av feil}

Grunnet mistanke om underrapportering ble den nye ordningen innført. Før 2012 ble slike meldinger rapportert inn til Statens helsetilsyn, men etter at den nye ordningen ble innført, meldes det til Nasjonalt kunnskapssenter for helsetjenesten. Meldingene skulle frikobles tilsyn og man skulle fokusere på å lære av feil. I 2010 ble det rapportert om 2000 feil, mens det i 2013 kom inn 9500 meldinger.

Økningen kan, ifølge forskerne, skyldes både anonymisering av meldingene, en overgang fra papir til digital innmelding, og at det har vært kampanjer som har gitt stor oppmerksomhet rundt pasientsikkerhet, skriver de på gemini.no, siden for forskningsnytt fra NTNU og Sintef (1).

- En del av kriteriene som er satt for hva som skal meldes, gir rom for tolkning og de blir også tolket ulikt, sier prosjektleder Jan Wilhelm Lippestad, seniorrådgiver ved SINTEF.

\section{Ingen pasientinvolvering}

I det nye meldesystemet går meldingene digitalt og direkte fra helsepersonell til Kunnskapssenteret uten involvering fra pasient. Til tross for at det i den nye melde- ordningen stilles krav til brukerinvolvering, finnes det lite som bidrar til det.

- Sakene ses fra et fagperspektiv og tar ikke hensyn til hvordan pasienten opplever situasjonen, sier Lippestad.

Et ledd i den nye meldeordningen var også at ved mistanke om alvorlig systemsvikt skulle Kunnskapssenteret melde videre til Helsetilsynet. Av de totalt 9500 sakene ble det ikke meldt inn én eneste slik hendelse i løpet av det første hele driftsåret, 2013.

Lippestad stiller seg spørrende til om metodene er gode nok til å avdekke alvorligheten $i$ en enkelthendelse og om de klarer å sette enkelthendelsen inn i en kontekst. - Det er et tidkrevende arbeid, siden et behandlingsforløp kan involvere mange avdelinger og faggrupper i spesialisthelsetjenesten og kommunehelsetjenesten, sier han til gemini.no.

\section{Fortsatt i innkjøringsfasen}

I begynnelsen skulle Kunnskapssenteret gi tilbakemeldinger på hver rapport som kom inn fra helseforetakene. På grunn av den store pågangen strakk ikke ressursene til, og Sintef mener at de heller burde konsentrere seg om å samle likelydende meldinger for så å lage gode læringsnotater.

\section{Elisabeth Jacobsen}

Tidsskriftet

\section{Litteratur}

1. gemini.no. http://gemini.no/2015/01/ fortsatt-underrapportering-av-svikt/ (23.1.2015)
«Sakene ses fra et fagperspektiv og tar ikke hensyn til hvordan pasienten opplever situasjonen»

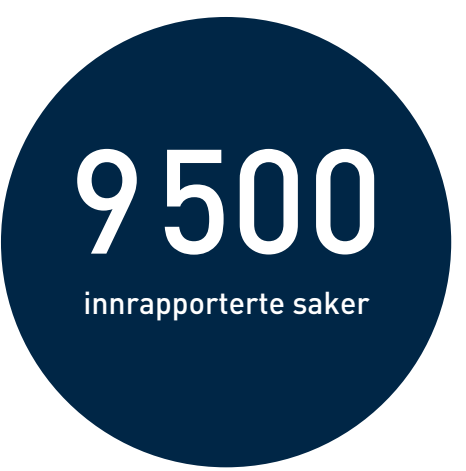

